\title{
La construcción del ideal sobre el amor materno en dos periódicos de Guadalajara y Torreón (1922-1950)*
}

\author{
The Construction of the Ideal of \\ Maternal Love in Two Newspapers in \\ Guadalajara and Torreón (1922-1950)
}

\author{
Rogelio Jiménez Marce ** \\ (D) https://orcid.org/0000-0003-2103-0180 \\ Instituto de Ciencias Sociales y Humanidades "Alfonso Vélez Pliego" \\ Benemérita Universidad Autónoma de Puebla, México \\ rojimarc@yahoo.com.mx
}

Resumen: El objetivo de este trabajo es analizar cuál fue el discurso periodístico que se construyó en torno a la maternidad en la primera mitad del siglo xx y qué prácticas se llevaron a cabo para afianzar su culto en las ciudades de Guadalajara y de Torreón. Para conocer las representaciones sobre la madre y las festividades que se realizaban en su honor, se examinó el discurso de dos periódicos locales (El Siglo de Torreón y El Informador). El estudio muestra que los imaginarios de la madre se construían en torno a tres aspectos: biológico (su condición innata para la procreación), religioso (su vinculación con la

* Esta investigación se inscribe en el marco del proyecto viep titulado "Celebraciones cívicas y modernidad en la ciudad de Puebla".

** Doctor en Antropología, CIESAs. Sus líneas de investigación son la historiografía, la historia cultural y la historia religiosa.

Cómo citAR: Jiménez Marce, M. (2021). La construcción del ideal sobre el amor materno en dos periódicos de Guadalajara y Torreón (1922-1950). Secuencia (110), e1796. DoI: https://doi.org/10.18234/secuencia. v0i110.1796

\section{c) 98}

Esta obra está protegida bajo una Licencia Creative Commons Atribución-NoComercial 4.0 Internacional. 
virgen María) e ideológico (su utilización como bandera de algunas causas políticas). Aunque los rotativos no apoyaban las ideas "modernas" respecto a la maternidad, sí se pugnó por mejorar sus condiciones como una manera de conducir al país por los ámbitos de la modernidad.

Palabras clave: maternidad; día de la madre; historia de la prensa; Guadalajara; Torreón.

Abstract: The purpose of this paper is to analyze the journalistic discourse that developed around motherhood during the first half of the 20th century and the practices implemented to strengthen its cult in the cities of Guadalajara and Torreón. To learn about the representations of mothers and the festivities held in their honor, the author analyzes the discourse of two local newspapers (El Siglo de Torreón and El Informador). The paper shows that imaginaries concerning the mother were based on three aspects: biological (her innate capacity for procreation), religious (her connection with the Virgin Mary) and ideological (her use as a banner for certain political causes). Although the newspapers did not support "modern" ideas on motherhood, they did seek to improve its condition as a means of leading the country into the realm of modernity.

Keywords: motherhood; mother's day; history of the press; Guadalajara; Torreón.

Recibido: 17 de octubre de 2019 Aceptado: 6 de mayo de 2020

Publicado: 3 de mayo de 2021

Para Eva Berenice

ـ a institución del día de las madres en México comenzó el 13 de abril de que el 10 de mayo se consagrara al enaltecimiento de las madres, con la finalidad de que se comprendieran "ciertos conceptos de la vida de familia y atañederos al hogar". Advertía que el respeto a la madre debía convertirse en "una religión", en uno de los "deberes más gratos y fundamentales de la vida" y en 
un "homenaje de amor y de ternura" por los "sacrificios" que realizaba. La iniciativa de este diario, considerado de tendencia "conservadora moderada" y vinculado con el gobierno (Burkholder, 2009, pp. 1370, 1398; Santillán, 2010, pp. 92, 98), sería secundada por rotativos como El Demócrata y por el Secretario de Educación Pública, José Vasconcelos, quien encargó a los profesores que se convirtieran en los promotores de la celebración. ${ }^{1}$ De acuerdo con El Demócrata, la festividad tenía el objetivo de rechazar un suceso "execrable": la impresión de cartillas contra la natalidad en las que se consideraba a la "familia como un estorbo para la realización de los destinos individuales". En este sentido, la celebración ayudaría a reafirmar una maternidad lesionada a causa del "interés sombrío" de "algún funcionario" o de un partido políti$\mathrm{co}^{2}$ El 11 de mayo, el periódico anunció, con gran emoción, que a lo largo del país se realizaron homenajes de "amor y gratitud a las madres mexicanas". El éxito de la iniciativa se manifestaba en el hecho de que "no había una sola persona que no llevara un ramo en las manos, o una flor en el ojal". Aunque el festejo a la madre no era una idea original de Alducín, ${ }^{3}$ pues en Estados

${ }^{1}$ El que se le asignara esta tarea a los profesores se explicaba por el hecho de que se les consideraba unos misioneros políticos y culturales. De hecho, se concebía la educación como un medio para politizar, nacionalizar y contrarrestar la influencia "nociva" de la Iglesia (Knight, 2010, p. 1301).

2 Redacción, "El Día de las Madres, una fiesta que nació en Excélsior". Recuperado de https://www.excelsior.com.mx/nacional/2017/05/09/898251 Aunque en El Demócrata no se mencionaba, el gobernador de Yucatán, Felipe Carrillo Puerto, promovió la educación sexual y el empleo de anticonceptivos. También publicó un folleto, traducido del inglés cuya autora era la enfermera y activista estadunidense Margaret Sanger, intitulado Regulación de la natalidad o Brújula del hogar que apelaba a la utilización de métodos anticonceptivos para evitar un embarazo. De hecho, Sanger abrió, en 1916, la primera clínica pública de control de la natalidad en Estados Unidos. Sthepanie Coontz (2006) plantea que en las primeras dos décadas del siglo xx, las relaciones sociales entre hombres y mujeres se desarrollaron en un plano de mayor igualdad, además de que tuvieron un mayor acceso a información referente al control de la natalidad y la sexualidad (p. 258). Por otra parte, no era una casualidad que en Yucatán se promoviera el folleto, pues ahí se realizó en 1916 el Primer Congreso Feminista, impulsado por Hermila Galindo, y existía un grupo de mujeres que compartían ideas liberales y feministas (Ávila, 2004, pp. 91-96; Gutiérrez, 2017, pp. 51-52; Santillán, 2010, p. 99).

3 E. Borrego, "Breviario. Diez de Mayo", El Siglo de Torreón, 10 de mayo de 1929, pp. 3, 6; "En el día de la madre", El Siglo de Torreón, 10 de mayo de 1942, p. 5; "Cabezas", El Siglo de Torreón, 10 de mayo de 1946, p. 4. En la película Mi madrecita (1936), los productores Rafael Arzos y Luis Gene reconocían a Rafael Alducín como el introductor de "la gloriosa fiesta del día de las madres". Sin embargo, en El Siglo de Torreón se mencionaba, en 1946, que ese honor le correspondía al lagunero Teodoro González, quien trabajó al lado de Ann Jarvis y le propuso esta idea a Alducín cuando se desempeñó como jefe de publicidad en Excélsior. No todos estuvieron 
Unidos se celebraba desde 1914 merced a la iniciativa de Ann Marie Jarvis, lo que nos interesa en este trabajo es entender la manera en cómo se construyó el ideal del amor materno desde el discurso periodístico, cuáles fueron las características que se le atribuyeron y, sobre todo, cuál fue el impacto de esta idea en dos ciudades (Guadalajara y Torreón) del interior del país, a fin de determinar qué ideas se compartían y cuáles fueron las particularidades de las festividades que se realizaron en su honor. Aunque existen idealizaciones que se pueden compartir, las prácticas sociales son diferenciadas en función de las características que cada población le imprime. ${ }^{4}$

Para tal fin, se ocuparon dos periódicos estatales: uno de Coahuila, El Siglo de Torreón, y uno de Jalisco, El Informador, para comprender sus opiniones sobre las ideas que se tenían sobre la madre y las festividades que se efectuaban en su honor. La utilización de la prensa se sustenta en el hecho de que esta constituye un medio indispensable para socializar noticias y son espacios de expresión de ideas, opiniones, debates y críticas. La prensa no sólo influye en la opinión pública, sino que forma conciencia política entre sus lectores (Cruz, 2013, pp. 11, 296). La elección de los periódicos se realizó con base en los siguientes aspectos: eran referentes de la opinión pública en sus respectivas ciudades, dedicaron amplios reportajes a las actividades del 10 de mayo y tienen una trayectoria de larga duración pues se fundaron en las dos primeras décadas del siglo xx. El trabajo se ubica entre los años de 1922 a 1950, mismos que se caracterizaron por los procesos de urbanización e industrialización, el desarrollo de los medios de comunicación y de los hábitos de consumo, y por el afianzamiento de un estado nacionalista que buscó regir los destinos de sus habitantes por medio de la instrumentación de proyectos educativos y culturales (Rocha, 1996, pp. 120, 128). En el caso específico de Guadalajara, la ciudad experimentó un notable aumento demográfico, de 131000 en la década de 1920 pasó a 235000 en los años cuarenta, se diversificó la base industrial cuya prioridad era la producción de bienes de consumo, aumentó el número de comercios y de instituciones crediticias, y se observó un crecimiento urbano como consecuencia de una amplia demanda de vivienda (Muriá, 1988, pp. 522-525), situación similar a la experimentada por Torreón que al inicio

de acuerdo con la idea, pues algunos periodistas la consideraban una "idea importada de otras tierras", una "tradición nueva" imitada de los "vecinos del norte".

${ }^{4}$ Van Dijk (1996, p. 12) menciona que las prácticas sociales articulan las creencias o representaciones sociales específicas de los grupos, así como aspectos socioculturales como el conocimiento, las actitudes, las normas, los valores y las ideologías. 
de la década de 1920 contaba con 50902 habitantes y al finalizar tenía 64 724, población que superaba la de las demás capitales de los estados norteños, con excepción de Monterrey. El rápido crecimiento de Torreón se explicaba por la alta productividad de sus tierras cuyo sistema de irrigación representaba $11 \%$ del total de la nación, lo cual les permitía producir más de la mitad del algodón y la séptima parte del trigo que se cosechaba en México. Esta prosperidad decaería después de 1936, año en el que el presidente Lázaro Cárdenas decidió repartir las tierras de La Laguna (Vargas, 1999, pp. 11, 89-90, 144-202).

El objetivo de esta investigación es analizar cómo a través de la prensa, entendida como un medio de expresión y generación de opinión, se construyó un discurso en torno a la maternidad, como la principal condición de la mujer, en la primera mitad del siglo xx y qué prácticas se llevaron a cabo para afianzar el culto a la madre. En este sentido, el amor materno ${ }^{5}$ se entiende como un fenómeno sociocultural y una construcción simbólica en el que intervienen una serie de discursos y de prácticas que buscan darle un sentido específico, y que adquieren nuevas connotaciones de acuerdo con los cambios sociales, económicos, culturales y políticos en un determinado momento de la historia (Arvelo, 2004, pp. 93-94, 96; Badinter, 1981, pp. 117-118, 166-168; García, 2015, pp. 38, 40; González, 2008, pp. 93, 95; Palomar, 2005, pp. 36, 41, 43; Rocha, 1996, p. 119; Sánchez, 2016, p. 257). El proceso de definición de la maternidad, en el México de las décadas de 1920 y 1930, estuvo marcado por influencia de las teorías médicas, en específico las eugenésicas, y de los grupos políticos que buscaban la transformación de la nación después de la revolución (Castilla, 2005, pp. 191-193). Esta visión se modificaría en las décadas siguientes cuando adquirieron preponderancia asuntos como la etnicidad y el crecimiento demográfico. ${ }^{6}$ El texto se conforma de tres apartados: en el primero se presentan las ideas que justificaban socialmente el festejo del día de la madre; en el segundo se explora la concepción de la maternidad y las cualidades que caracterizaban al amor materno; y en el tercero se muestran

${ }^{5}$ El ideal del amor materno apareció en la modernidad que lo consideraba un valor de la civilización y un código de buena conducta. Este formaba parte del proceso de transformación de la familia, de los afectos y una forma de control de los cuerpos para potencializar la productividad. Así, el ser y deber ser de la mujer se construyó en torno al sexo. Alicia Oiberman (2005, pp. $116,123)$ plantea que para comprender el amor maternal también se deben entender los aspectos psicológicos, pues como fenómeno psico-biológico se presenta ambivalente, ambiguo y complejo.

${ }_{6}$ Ricardo Pérez (1999, p. 180) menciona que en su búsqueda de la identidad del mexicano, las expresiones culturales del nacionalismo revolucionario utilizaron argumentos que iban desde lo científico hasta lo circunstancial. 
las celebraciones en las ciudades de Torreón y Guadalajara, con el fin de comprender qué actividades se realizaban y su impacto en la población.

\section{UNA "FELIZ IDEA": EL INICIO DE LA CELEBRACIÓN A LA MADRE}

La iniciativa de Excélsior sería alabada por El Siglo, periódico cuyo primer número se publicó el 2 de enero de 1922 en la ciudad de Torreón, Coahuila, ${ }^{7}$ en su editorial del 10 de mayo de ese año, pues era loable la propuesta de celebrar a la madre por considerarla un "homenaje de admiración, de respeto y de amor". ${ }^{8}$ Este asunto se volvió a mencionar hasta $1927,{ }^{9}$ y en los siguientes años se insistió en la necesidad de honrarla porque la nobleza del amor materno ayudaba a "mejorar en algún sentido al género humano o cuidar que no se vuelva uno más malo"..$^{10}$ El discurso sobre el día de la madre adquirió ciertos matices que eran producto de las circunstancias sociales y políticas del momento, tal como sucedió en 1928 cuando se realizó una asociación entre la madre y la patria, pues se decía que las dos formaban "un solo amor y un solo deber". Así, el amor a la madre constituía un "homenaje a la patria". ${ }^{11}$ En 1943, y con motivo de la entrada de México a la segunda guerra mundial, se volvió a asociar a la madre con la patria, pues la primera guardaba en su corazón la "sustancia más pura de la patria" y estaba dispuesta a entregar a sus hijos para "la defensa de nuestra patria y de nuestra nacionalidad" ${ }^{12}$ Este discurso sería utilizado unos años después por el Movimiento Económico Nacional, al afirmar que la patria era la "madre común de todos los mexicanos, una madre

7 A partir del 1 de enero de 1928, el periódico modificó su nombre a El Siglo de Torreón.

8 "Día de las madres", El Siglo, 10 de mayo de 1922, pp. 1, 3-4.

9 "Al margen", El Siglo, 10 de mayo de 1927, p. 1.

${ }^{10}$ J. S. Díaz, "El amor de los hijos", El Siglo de Torreón, 10 de mayo de 1930, p. 3.

${ }^{11}$ "Al margen", El Siglo de Torreón, 10 de mayo de 1928, p. 1; "Al Margen”, El Siglo de Torreón, 10 de mayo de 1930, p. 1; Palomar (2005) y Oiberman (2005) plantean que las políticas natalistas fueron las que postularon la idea de la maternidad como un deber patriótico.

12 "Amarga despedida", El Siglo de Torreón, 10 de mayo de 1940, p. 2; I. Herrera, "Día sublime y de la realidad. Día de la madre”, El Siglo de Torreón, 10 de mayo de 1943, pp. 4, 6. El 10 de mayo de 1940 se incluyó una fotografía con el siguiente texto: "La anciana despide con profunda tristeza al hijo soldado que se aleja cumpliendo un deber con la patria [...] Este sacrificio materno de entregar al hijo de sus entrañas para que la metralla lo despedace, simboliza en estos momentos [...] el panorama de nuestra dolorida Humanidad en que la Madre es la víctima por excelencia. La Madre que sufre, por la Patria, por el hijo y por ella misma". 
sublime en cuyo regazo crecimos", la cual no sólo proporcionaba cobijo sino que buscaba un "mañana mejor" para sus hijos, motivo por el cual se incentivaba a comprar artículos nacionales como una manera de demostrar el amor a la madre-patria. ${ }^{13}$

La celebración del día de la madre también sirvió como pretexto para promover ideologías políticas, tal como lo hizo Benigno V. Jiménez quien declaraba que este festejo, arraigado en la "conciencia nacional", impulsaba la introducción de los principios revolucionarios en las familias y, con ello, ayudaría a acabar con las "fuerzas devastantes del fanatismo y de la ignorancia”. ${ }^{14}$ Por su parte, el Partido Acción Nacional (PAN), en 1940, publicó un desplegado en el que mencionaba que el hogar, creado por la madre, era la base de la civilización y de su seno emergían formas sociales, como la familia, y elementos políticos como la ciudad, el gobierno y el Estado. Como la nación se asimilaba con la familia, la madre se convertía en la principal promotora del progreso, pues ella inculcaba los fundamentos religiosos y difundía los principios de la economía moderna y de la salubridad. Al ser la madre la "influencia decisiva de la evolución de los pueblos", debía ayudar en la transformación de los "aspectos materiales y espirituales de la sociedad", tarea que podía realizar en su faceta de educadora de sus hijos, los "ciudadanos del mañana", y de su esposo, "el ciudadano de hoy", a quienes debía convencer para que ingresaran a las filas de ese partido político y de esa manera, contribuir al cambio en México. ${ }^{15}$ Aunque este anuncio no se volvió a publicar, daba cuenta del papel que la madre debía desempeñar en la conformación de la realidad política. El PAN no buscaba incluirla en los procesos políticos, pero sí se le pedía que influyera en aquellos que podían hacerlo. ${ }^{16}$ Algunos escritores utilizaron el 10 de mayo para reflexionar sobre la condición de la madre en la sociedad. Por ejemplo, Roberto Quiroz indicaba que en México no se comprendía el "deber filial", pues los hijos no cuidaban a sus madres, situación que evitaba que se contara con "madres vigorosas, prolíficas y longevas" que ayudarían a construir un "país fuerte".

13 "La Patria es nuestra Madre", El Siglo de Torreón, 10 de mayo de 1950, p. 13.

${ }^{14}$ B. V. Jiménez, "Misión que enaltece y diviniza”, El Siglo de Torreón, 10 de mayo de 1932, p. 3.

15 R. Morelos, "Loor a las Madres", El Siglo de Torreón, 10 de mayo de 1940, p. 2.

${ }^{16}$ Un discurso similar fue esbozado por el Partido Revolucionario de Unificación Nacional (PRUN) que apelaba a que las mujeres hicieran valer sus derechos de mexicanas "por conducto de los hombres que amas y sobre los que puedes influir” (Santillán, 2010, p. 98). 
Ante esta situación, pedía la promulgación de un código familiar que garantizara su protección. El escritor advertía que cuando el culto a la madre se volviera "consciente" y "espontáneo", se daría un paso de "alta significación social" en virtud de que el amor a la madre era el mismo que se le tenía a la patria y a la humanidad. En este mismo sentido se expresaba Samuel Silva, quien indicaba que rendir homenaje a la madre constituía una "expresión elocuente del sentimiento más depurado" y evidenciaba el "progreso moral" alcanzado por un pueblo. ${ }^{17}$ Por su parte, Roberto Morelos consideraba lamentable que el 10 de mayo no tuviera ningún significado en "el campo y lugares apartados". Los campesinos desconocían ese "verdadero amor" y concebían la maternidad como un "acto biológico" e "instintivo", motivo por el cual mostraban un alejamiento de la "madre campesina". Lo anterior podría modificarse, a decir del escritor, gracias a la conmemoración del 10 de mayo y no por la educación que resultaba "deficiente" en el medio rural. Como los campesinos preservaban sus costumbres e ideologías, Morelos creía que la festividad coadyuvaría a que se aceptara la maternidad como un bien para la patria. En este sentido, el gobierno no sólo debía impulsar esta celebración entre las mujeres del campo, sino otorgarles apoyos en materia de salubridad y asistencia. En un anuncio publicado en 1950 por la Unión Central de Sociedades Ejidales de la Confederación Nacional Campesina, se mencionaba que ella era la "base del hogar", la "abnegada y fiel compañera del trabajador del campo" y su acompañante en las "luchas por el mejoramiento social y económico del campesinado regional". ${ }^{18}$ Por la consonancia social que alcanzó el 10 de mayo, David Quevedo, en 1950, la consideraba "una de las máximas solemnidades en nuestra patria", comparable a celebraciones cívicas como la independencia y la revolución. ${ }^{19}$

En el caso de El Informador, rotativo editado en la ciudad de Guadalajara y cuyo primer número se imprimió el 5 de octubre de 1917, la primera noticia sobre el día de las madres apareció en 1925, es decir tres años después

${ }_{17}$ R. Quiroz, "A la madre mexicana", El Siglo de Torreón, 10 de mayo de 1935, p. 2; S. Silva, “iSalve, madres!”, El Siglo de Torreón, 10 de mayo de 1944, pp. 4, 10.

${ }_{18}^{18}$ R. Morelos, "Loor a las madres", El Siglo de Torreón, 10 de mayo de 1940, pp. 2-3; "La Unión Central de Sociedades Ejidales”, El Siglo de Torreón, 10 de mayo de 1950, p. 15. El papel otorgado a la madre campesina fortalecía la idea de que los campesinos eran la base del país (Pérez, 1999, p. 185). Es importante mencionar que durante el gobierno de Cárdenas se buscó darle mayor presencia política a los obreros y campesinos, de forma que, a partir de 1937, se permitió que las organizaciones obreras y campesinas designaran candidatos a puestos de elección popular.

${ }^{19}$ D. Quevedo, “¡Loor a las madres!”, El Siglo de Torreón, 10 de mayo de 1950, pp. 4, 11. 
de la propuesta de Alducín, y sólo informaba sobre los festivales que se realizarían en algunas escuelas primarias. ${ }^{20}$ Esta situación cambió seis años después cuando se publicó una nota en la que se manifestaba que la celebración se esperaba con "gran impaciencia", al ser una "devoción aceptada por todas las clases sociales" y en la que los hijos buscaban "ofrendar a las autoras de sus días el más rendido homenaje de admiración y de cariño". En los artículos se evidenciaba que la celebración debía trascender el ámbito público, los actos sociales realizados en escuelas y teatros, para convertirse en un asunto privado, pues los hogares debían convertirse en "centros de alegría” en donde los vástagos les ofrendaran "grandes honores" y "especiales distinciones" a sus madres. ${ }^{21}$ Sin embargo, se advertía que el culto a la madre no debía circunscribirse a un día, sino que se le debía honrar diariamente. ${ }^{22} \mathrm{El}$ "sincero homenaje familiar" no sólo se volvía la "máxima expresión" del amor del hijo por la madre, sino que también representaba un "símbolo expresivo de la comunión del corazón de las madres con sus hijos", sentimiento que se debía reafirmar en un contexto enmarcado por la "destrucción de las íntimas fruiciones familiares" como el respeto y la veneración de los padres. Como el 10 de mayo era el "día de fiesta de los hogares mexicanos", las ceremonias familiares vigorizaban en los "corazones infantiles" aquel "afecto purísimo". Para afianzar el vínculo entre madres e hijos, se estimaba que la conmemoración debía extenderse a todo el país y se debían organizar festejos que unieran el día del niño con el de la madre, a fin de fomentar "vínculos duraderos" que fortalecieran el significado del "culto social público".

Lo ideal, según el periódico, era que este "culto secular" afianzara el amor del hijo por la madre y de la madre por el hijo, lo cual ayudaría a que la festividad se volvería "más hermosa, radiante y sincera" por sustentarse en la "religión del amor mutuo". ${ }^{23}$ Este planteamiento se podía observar, por ejemplo, en la película Mi madrecita (1940), pues la protagonista mencionaba: "dicen que hoy es el día de las madres, para mí es el día de mis hijos". ${ }^{24}$ En El

20 “Hoy se celebrará el “Día de la Madre”, El Informador, 10 de mayo de 1925, p. 1.

21 "Sincero homenaje de gratitud y respeto se rendirá hoy a las madres". El Informador, 10 de mayo de 1931, p. 1; “¡Honor a las madres!”, El Informador, 10 de mayo de 1932, pp. 1-2.

${ }^{22}$ Redacción, "Día de las madres", El Informador, 10 de mayo de 1933, p. 3; S. Silva, "El amor a la madre", El Siglo de Torreón, 30 de abril de 1947, p. 4.

${ }^{23}$ Redacción, "En el regazo de la madre”, El Informador, 10 de mayo de 1941, p. 3; Redacción, "Honor a nuestra madre", El Informador, 10 de mayo de 1942, p. 3.

${ }^{24}$ Anuncio, El Siglo de Torreón, 10 de mayo de 1940, p. 4; Anuncio, El Informador, 10 de mayo de 1940, p. 5. Mi madrecita se estrenó en 1940 y fue dirigida por Francisco Elías. Fue pro- 
Informador también se realizó una asociación entre la madre y la patria, a la cual se le designaba como la "madre mexicana", la "madre de las madres", la "madre común a todos los mexicanos" y la "más mexicana". La madre patria, al igual que la biológica, sostenía y cuidaba a sus hijos, les daba ser y forma, lenguaje y espiritualidad. Con la entrada de México a la segunda guerra mundial, los articulistas pidieron el sacrificio de los hijos por su madre patria. ${ }^{25}$ Con el fin de la conflagración mundial, se sugirió que la figura de la madre se convirtiera en el "baluarte de la paz" ${ }^{26}$ Bajo su égida, se construiría un mundo lleno de paz y amor, con lo que la madre se tornaba madre-humanidad. El discurso sobre la madre siempre hacía referencia a la viva y, sólo de manera ocasional se mencionaba a la fallecida para recordar la "venerada figura" de aquella que formó "buenos hijos". En algunas ciudades, como Torreón, los hombres ponían un clavel rojo en referencia a las madres vivas y uno blanco para recordar a las difuntas. ${ }^{27}$ Para "P. Lussa", la instauración del festejo del día de las madres constituía una prueba de que México avanzaba por el camino de las naciones "más notables y prominentes", pues ellas se convertían en un objeto de reconocimiento social. Esta postura era compartida por José G. Montoya, quien consideraba que honrar a las madres ayudaba a enmendar un "error imperdonable".

Otro articulista afirmaba que la fiesta del 10 de mayo constituía una "esperanza" para México, pues los pueblos que honraban a sus madres se conducían por el "camino del amor puro, de la conciencia sana y de la superación espiritual", elementos que formaban la base del "progreso material". Sin embargo, "P. Lussa" advertía que la celebración original no tenía la intención de

tagonizada por Sara García, Julián Soler, Julieta Palavicini, Víctor Urruchúa y Julio Villarreal. El Informador indicaba que esta película constituía "el más ferviente tributo de admiración y cariño a la abnegada madre mexicana y una sabia enseñanza a los hijos". Este filme tuvo un enorme éxito de taquilla. Es de destacar que la primera producción que presentaba a la madre abnegada y sufrida fue Madre querida (1935) del director Juan Orol. Otras películas que seguían esta misma tónica fueron Madres del mundo (1936), Cuando los hijos se van (1941), La gallina clueca (1941), y Madre adorada (1948), entre otras (Melche, 1997, p. 24; Monsiváis, 2004, pp. 169-170).

${ }^{25}$ A. Rey, “¡Madre!”, El Informador, 10 de mayo de 1931, p. 3; Redacción, "Honor a nuestra madre”, El Informador, 10 de mayo de 1942, p. 3; Redacción, “ ¡Madre!", El Informador, 10 de mayo de 1948, p. 4.

${ }^{26}$ B. X. Pérez, "La madre: el verdadero baluarte de la paz", El Siglo de Torreón, 10 de mayo de 1946, pp. 4, 11.

${ }_{27}$ "Homenaje a la madre", El Informador, 10 de mayo de 1939, p. 1. 
rendir un homenaje a la madre, sino de aumentar las ventas de productos. ${ }^{28}$ En este mismo sentido se expresaba José T. Laris, quien indicaba que no había razones históricas que justificaran la fecha de la celebración y tampoco era una festividad novedosa, pues el culto a la madre era tan antiguo como la humanidad..$^{29}$

\section{LA MATERNIDAD: UN “DON DEL CIELO”}

A finales del siglo xIX, el amor materno se consideraba igual al "amor del cielo" por su carácter "inagotable" y fecundo" ${ }^{0}$ y se presentaba a la virgen María como el modelo a imitar por las madres, debido a que ella constituía, en sí misma, la expresión plena del amor que trascendía lo sensible hacia lo divino (González, 2008, p. 97). Como la madre continuaba con la labor divina, adquiría un carácter sagrado que se manifestaba en virtudes como la sublimidad, la ternura y el amor puro. Como "ángel tutelar" de sus vástagos, a la madre le correspondía inculcar valores sociales y religiosos, velar por su felicidad, sufrir con sus desgracias y buscar su redención cuando cometían errores. ${ }^{31} \mathrm{El}$ "instinto materno" le permitía descubrir sus faltas y por medio de "consejos impregnados de ternura", lograba "mover sus corazones" y corregir sus comportamientos. Sin embargo, se advertía que su "noble y generoso corazón" podía tornarse "débil, impotente y degradado" a causa del pecado, motivo por el cual debía cultivar las virtudes cristianas en el entendido que en ella residía la "felicidad humana" y el "espíritu del pueblo", esto es, las costumbres y virtudes de una sociedad. ${ }^{32}$ Esta visión sobre la madre continuó en las siguientes décadas, aunque adquirió nuevas especificidades como consecuencia de los cambios sociales, culturales e intelectuales que se generaron en

${ }^{28}$ P. Lussa, "Charlas de sobremesa. Madres", El Informador, 10 de mayo de 1939, p. 3; J. G. Montoya, "De nuestros lectores. Diez de mayo", El Informador, 10 de mayo de 1939, p. 5; “'Madre!”, El Informador, 10 de mayo de 1948, p. 4.

${ }^{29}$ J. T. Laris, “¡La madre!”, El Informador, 10 de mayo de 1939, p. 3.

30 "Mes de María en San Miguel", La Voz de México, 3 de junio de 1887, p. 2; Martha Eva Rocha (1996, pp. 122-123) indica que la educación moral de las mujeres, a fines del xix, exaltaba la maternidad que se consideraba una característica innata de las mujeres.

31 "El nacimiento de María", La Voz de México, 8 de septiembre de 1888, p. 1; "La madre cristiana”, La Voz de México, 20 de junio de 1897, p. 1.

32 "Correspondencia de los Estados. Durango", La Voz de México, 13 de octubre de 1888, p. 2; "Un llamamiento a la mujer", La Voz de México, 15 de octubre de 1897, p. 1. 
la primera mitad del siglo xx. Así, en 1923, María Luisa Castellanos equipara el amor de Dios con el de la madre. A ella se le concebía como la "genuina representación de la Divinidad sobre la tierra”, pues en su seno se encerraba el "misterio amoroso" de la maternidad que, en sí mismo, se concebía como la "obra creadora por excelencia". ${ }^{33}$ En este sentido, el amor a la madre representaba el amor a la creación. Cuando la madre cumplía con el "más primordial de sus deberes", ${ }^{34}$ adquiría un "halo divino" que la diferenciaba de sus congéneres pues la mujer sólo proporcionaba "goces de la tierra", pero la mujer-madre conducía a las "delicias del cielo".

La virgen María se convertía, en este sentido, en el ejemplo que debía seguir la mujer-madre, quien alcanzaba la santificación cuando nacía su hijo, lo cual implicaba pensar en una mujer perfecta que adquiría las "virtudes del espíritu”, tales como el sacrificio, la abnegación, la resignación, el dolor, el sufrimiento, el cariño y la ternura, las cuales le ayudaban a convertirse en la guía y "símbolo radiante" de sus hijos. La belleza espiritual de la mujer-madre se manifestaba en dos planos: físico que la volvía "más hermosa, más fuerte, más lozana, más deslumbrante", y moral que se manifestaba en "el buen consejo, la sana intención, el bien obrar, el camino recto del amor, la bondad, la fraternidad y la nobleza". Estas cualidades la convertían en una "madre-modelo" cuyas acciones llenaban de "luz y amor al mundo". ${ }^{35}$ El elogio de la madre-modelo constituía una forma de ensalzar los valores morales de la sociedad, pues ella cumplía con el deber ser de la mujer. ${ }^{36}$ Esta postura sería criticada por la escritora Catalina D'Erzell, quien indicaba que todas las madres debían ser veneradas, pues la maternidad purificaba su alma. Como ninguna concepción podía ser objeto de juicio, proponía que se hablara de

${ }^{33}$ M. L. Castellanos, “¿Qué es el amor?”, El Siglo de Torreón, 2 de agosto de 1923, p. 5.

${ }^{34}$ C. D’Erzell, "La plegaria de la madre", El Informador, 10 de mayo de 1931, p. 10. Catalina D’Erzell afianzaba la idea de la maternidad como destino de la mujer cuando afirmaba "ahí estaban ustedes, en mis juegos, en mi muñeca, en mi infancia de mujer. Ya latían en mis pensamientos y en los latidos del corazón".

35 “Día de las madres", El Siglo, 10 de mayo de 1922, p. 1; R. Quiroz, "La mujer madre", El Siglo de Torreón, 10 de mayo de 1933, p. 3; "Honor a nuestra madre", El Informador, 10 de mayo de 1942, p. 3; S. Silva, “jSalve, madres!", El Siglo de Torreón, 10 de mayo de 1944, pp. 4, 10; "El sentimiento maternal a través de los siglos", El Siglo de Torreón, 10 de mayo de 1948, pp. 4-5; "Madre", El Informador, 10 de mayo de 1949, p. 4.

36 "Al margen", El Siglo, 10 de mayo de 1927, p. 1; B. V. Jiménez, "Misión que enaltece y diviniza", El Siglo de Torreón, 10 de mayo de 1932, p. 3; I. Herrera, "Día sublime y de la realidad, día de la madre”, El Siglo de Torreón, 10 de mayo de 1943, pp. 4, 6; “¡Madre!”, El Informador, 10 de mayo de 1948, p. 4. 
"madres felices" y "sin ventura". Las primeras recibían "dones de bienestar y amor" por haber encauzado su vida por el "sendero recto", mientras que las segundas carecían del apoyo de un hombre y sólo contaban con su "retoño". En este punto, la autora mostraba que la maternidad, entendida como una "misión sagrada", no sólo ayudaba a ocultar la deshonra, sino que la convertía en una "madre buena" que era "consciente de sus responsabilidades" y que veía en su vástago "su estímulo, su recompensa, su sostén y su consuelo".

Lo contrario sucedía con aquella que abandonaba a su hijo en el asilo, pues no alcanzaba la reivindicación social ni el perdón. Ella viviría con el eterno "remordimiento" de haberlo desamparado. José T. Laris también creía que la maternidad transformaba a las mujeres, pues las que antes de casarse no eran "aptas para nada" sorprendían por su "arrojo y valentía" cuando se trataba de proteger a sus "cariños filiales". ${ }^{37}$ El cambio en la actitud de la mujer-madre se explicaba por dos factores: el primero era el sacrificio que implicaba la maternidad. El "dolor maternal", manifiesto en el parto, contribuía a purificar su alma y a hacer que renunciara a su condición de mujer para alcanzar el de madre. El segundo era su alejamiento de la vida social para entregarse por completo al "fruto de su vientre", hecho por el cual se le debía considerar una "heroína de la humanidad" por renunciar a su "belleza" y "juventud". Así, las "buenas madres" se distinguían por ser la "honra de su sexo" y el "ídolo de la familia". ${ }^{38}$ Entre las "buenas madres" también se establecía una diferenciación: a las jóvenes no se les podía rendir admiración por seguir en "estrecho contacto con las cosas mundanas". Una mujer que se comportaba de esa manera era una señora más que una madre. En contraste, la "buena madre" era aquella cuya vejez, prematura o natural, denotaba el "máximo sacrificio" realizado por sus hijos. ${ }^{39}$ La idea de una anciana como representación

${ }^{37}$ C. D'Erzell, "A las madres", El Siglo de Torreón, 10 de mayo de 1941, p. 6; J. T. Laris, "El culto a la madre y el 10 de mayo", El Informador, 10 de mayo de 1943, p. 3; T. L. Vidrio, "Salutación a las madres", El Informador, 10 de mayo de 1943, p. 12.

38 "Día de las madres", El Informador, 10 de mayo de 1933, p. 3; R. Quiroz, "A la madre mexicana", El Siglo de Torreón, 10 de mayo de 1935, p. 2; "Honor a nuestra madre”, El Informador, 10 de mayo de 1942, p. 3; S. Silva, “¡Madre!”, El Siglo de Torreón, 10 de mayo de 1943, pp. 4, 6; J. P. González, "El amor y el dolor", El siglo de Torreón, 10 de mayo de 1944, p. 4; E. Ávila, "Para el día de las madres", El Siglo de Torreón, 10 de mayo de 1946, pp. 4, 11; C. Vilchis, "Voces femeninas", El Informador, 10 de mayo de 1949, p. 6. La maternidad como un "regalo divino" puede observarse en la película Mi Madrecita, pues Enriqueta le mencionó a su esposo Gustavo que "tal vez por castigo de Dios no tenemos hijos".

${ }^{39}$ P. Lussa, "Charlas de Sobremesa. La madre", El Informador, 10 de mayo de 1950, pp. 4-5. Las imágenes sobre la buena madre tenían notables diferencias: la sociedad estadunidense la 
de la maternidad se comenzó a difundir, por medio de fotografías y anuncios publicitarios, después de 1936 y se afianzó en la década de $1940 .{ }^{40} \mathrm{La}$ cinematografía también retomó esta imagen, tal como se puede observar en películas como Mi madrecita y Cuando los hijos se van,${ }^{41}$ ambas protagonizadas por una envejecida Sara García.

Acorde con las políticas pronatalistas también se buscó enaltecer a la "madre prolífica". Por iniciativa de Excélsior, en 1930 se buscó premiar a las que tuvieran el mayor número de vástagos vivos, iniciativa que generó posiciones encontradas pues unos creían que el reconocimiento ayudaría a darle mayor relevancia a la celebración, mientras otros consideraban que no era un tema que conmoviera. De hecho, J. S. Díaz advertía que representaba lo mismo una madre con un hijo que la que procreó diez. ${ }^{42}$ Para refutar las críticas, se mencionaba que premiar a las "madres prolíficas" constituía un "justo reconocimiento" a las mujeres que eran "precursoras de la grandeza de la patria", pues engendrar "muchos hijos sanos" permitiría consolidar una "raza profunda, enorme pero no inerme". Sin embargo, en 1949, Guillermo de Luzuriaga se preguntaba si ellas eran felices, pues no bastaba procrearlos sino alimentarlos, vestirlos y educarlos. ${ }^{43} \mathrm{Si}$ por un lado se alababa a las "buenas mujeres" que dedicaban su vida a la maternidad, por el otro se criticaba a las

concebía como una mujer de clase media, casada, protestante, heterosexual, blanca y pendiente de sus hijos. En Italia se le caracterizaba como una mujer de senos grandes que amamantaba a sus hijos hasta una edad avanzada. En México se le identificaba con la "madrecita santa" que se convirtió en el icono del Estado nacionalista. En el estereotipo de la buena madre se conjugaba la ideología, la cultura y el nacionalismo (Castilla, 2005, pp. 198-199; Robles, 2005, pp. 53-54).

${ }^{40}$ Ricardo Pérez (1999, pp. 183-184) menciona que los estereotipos creados al amparo del nacionalismo revolucionario tuvieron una amplia difusión gracias al crecimiento de los medios de comunicación masiva. Carlos Alejandro Belmonte (2016, pp. 186-187) dice que el cine, entendido como industria y difusor ideológico, sería utilizado por el presidente Lázaro Cárdenas como un mecanismo de educación, de promoción de la unidad campesina y obrera, y una forma de organizar el mensaje revolucionario.

${ }^{41}$ La película se filmó en 1941. Fue protagonizada por Sara García, Fernando Soler, Joaquín Pardavé, Emilio Tuero y Carlos López Moctezuma, entre otros. Fue dirigida por Juan Bustillo.

42 "Al Margen”, El Siglo de Torreón, 10 de mayo de 1930, p. 1; S. J. Díaz, "El amor de los hijos”, El Siglo de Torreón, 10 de mayo de 1930, p. 3; Martha Santillán (2010, pp. 92, 102) indica que en 1941 se volvió a promover este concurso como una forma de acallar las voces que pedían, entre otras cosas, el derecho al voto. Desde su perspectiva, el modelo idealizado de la madre prolífica consolidó la alianza entre prensa, Estado y el ala conservadora de la sociedad (Santillán, 2019, p. 1123).

${ }^{43}$ F. Medina, "A la madre", El Informador, 10 de mayo de 1940, p. 7; I. Herrera, "Día sublime y de la realidad, día de la madre”, El Siglo de Torreón, 10 de mayo de 1943, pp. 4, 6; “iMadre!”, 
que por causa de las "torpezas y miserias" de la "vida moderna" buscaban limitar, o en el peor de los casos nulificar, su función maternal. Ellas buscaban satisfacer sus "placeres mundanos", sin darse cuenta de que la "ley de la maternidad" dictaba que su destino era el ser madres. En este sentido, se apelaba a que se prestara atención en la educación de la mujer, pues no se les preparaba para ser esposas. La coquetería y la vanidad no ayudaban a resolver los problemas de una casa, entre los cuales estaba la crianza de los hijos. José T. Laris coincidía en que la vanidad era la causante de que las mujeres olvidaran que ser madres era su destino, lo cual implicaba "sacrificios, privaciones, canas prematuras y la pérdida completa del sex appeal". Para vencer a la frivolidad, la indiferencia y la egolatría, se debía apelar a la "fortaleza de ánimo", la "ternura" y la "naturalidad de sus tendencias". ${ }^{4}$

Las anteriores ideas serían cuestionadas por Roberto Morelos en 1940, quien decía que los hombres habían "naturalizado" la maternidad, sin comprender el dolor físico, moral y espiritual que implicaba para las mujeres. Proponía que ellos acompañaran a sus esposas en la experiencia del parto, pues su perspectiva cambiaría: las críticas se volverían alabanzas y dedicarían su vida a "amarla, honrarla, protegerla y ampararla". Aunque reconocía en la maternidad lo "más sagrado, venerado y grande" de la mujer, pedía que no se juzgara a las que decidían evitarla. La ciencia había contribuido a que la maternidad dejara de concebirse como un "acto instintivo y animal" para convertirse en un hecho "premeditado y aceptado". Así, se le debía tener una mayor

El Informador, 10 de mayo de 1948, p. 4; G. Luzuriaga, El Siglo de Torreón, 10 de mayo de 1949, p. 4.

${ }^{44}$ E. Lanus, "Seamos ante todo mujeres", El Siglo de Torreón, 31 de marzo de 1935, p. 12; J. T. Laris, “iLa madre!”, El Informador, 10 de mayo de 1939, p. 3; S. Brito, "En el día de la madre”, El Informador, 10 de mayo de 1942, pp. 3, 6; J. T. Laris, "El culto a la madre y el 10 de mayo", El Informador, 10 de mayo de 1943, pp. 3, 12. Un ejemplo de la mujer vanidosa se encuentra en la película Cuando los hijos se van. En un diálogo sostenido entre Guadalupe Rosales (Sara García) y Mimí (Gloria Marín), la primera le mencionó que "es el destino de los padres pasar desvelos toda la vida por los hijos", a lo que ella respondió "sí, por eso yo me alegró de que no los tendré nunca". Sorprendida Guadalupe le preguntó: "qué se alegra usted de no tener hijos", y ella le contestó: "naturalmente, y Dios no me vaya a castigar mandándomelos. ¡Lagarto, Lagarto!". Ante tal situación, Guadalupe contestó "parece increíble que una mujer no quiera ser madre. En fin, cada uno tiene sus ideas”. En este caso, Mimí representaba a la vanidosa que se preocupaba más por su arreglo personal que por tener una familia a la cual cuidar. El surgimiento de una generación de mujeres que perseguía su propia liberación personal también sería estereotipada en otros países, tal como ocurrió en Estados Unidos con la flapper, en Francia con la garconne, en Brasil con la carioca, en Alemania con la Bubikopf, en Japón con la moga o modan gaaru y en Italia con la maschietta (Coontz, 2006, pp. 258-259). 
estimación y agradecimiento a las que decidían ser madres, motivo por el cual solicitaba la promulgación de leyes que las protegieran pues se les debía considerar "beneméritas de la humanidad". En esta misma tónica se expresaba María Lidia Urbina, quien afirmaba que no se podía esperar que las mujeres cumplieran con los papeles de antaño, pues, junto al hombre, ayudaban a la renovación de las estructuras sociales. ${ }^{45}$

\section{EL "AMOR DE TODOS LOS AMORES": EL AMOR MATERNO}

El amor materno era concebido como el "más puro y excelso en la esfera moral y de la belleza", pues no lo regía el egoísmo sino el deseo de querer el bien del ser amado. Como el amor de la madre se originaba en su alma "bondadosa" y "misericordiosa", se le consideraba el "más verdadero" por sus actos, cualidades y virtudes, el "más puro" por concentrar la esencia de su corazón y el "más desinteresado". Los hijos sentían una mayor afinidad por la madre, debido a que su amor era sentimental en tanto que el del padre era cerebral. El padre pensaba en su hijo, la madre lo sentía. Él buscaba un hijo sabio, ella procuraba hacerlo bueno. Las enseñanzas del padre se guardaban en la mente, las de la madre en el corazón. Él toleraba la separación de sus vástagos, ella no podía hacerlo porque eran la "carne de su carne". El amor del padre era terrenal, el de la madre era "eterno e incorruptible". El amor materno, por sí mismo, ennoblecía al linaje humano por encerrar desde "las formas más delicadas de la ternura hasta el ímpetu más arrebatado del sacrificio”. A través de él se podía acceder a lo divino y con ello, acercarse a la perfección. A la madre se le podía atribuir la invención del amor en la tierra. El amor materno era el "amor de los amores" por ser el primero que se conocía, el que se buscaba en los momentos de angustia y el que se deseaba en el lecho de la muerte. ${ }^{46}$ Aunque en

${ }^{45}$ R. Morelos, "Loor a las madres", El Siglo de Torreón, 10 de mayo de 1940, pp. 2-3; M. L. Urbina, "La mujer y el amor", El Siglo de Torreón, 29 de octubre de 1944, pp. 17, 19.

46 "Día de las madres", El Informador, 10 de mayo de 1933, p. 3; J. L. Vizcaíno, "Madre”, El Informador, 10 de mayo de 1937, p. 3; S. Silva, "¡Madre!”, El Siglo de Torreón, 10 de mayo de 1943, pp. 4, 6; J. T. Laris, "El culto a la madre y el 10 de mayo", El Informador, 10 de mayo de 1943, pp. 3, 12; J. Arderius, "La madre", El siglo de Torreón, 10 de mayo de 1943, p. 4; V. Alessio, "Gajos de Historia", El Informador, 10 de mayo de 1945, p. 4; S. Silva, "El amor de la madre", El Siglo de Torreón, 8 de mayo de 1947, pp. 4, 13; "El sentimiento maternal a través de los siglos", El siglo de Torreón, 10 de mayo de 1948, p. 4. 
la "buena madre" se manifestaban diversos atributos morales, lo que la convertía en un ser distinto eran tres factores: su "sublime abnegación", su "sacrificio continuo" y su amor "infinito". ${ }^{47}$ Ella siempre se mostraba pendiente de las necesidades, tanto materiales como espirituales, de sus hijos, encontraba "palabras de aliento" y "caricias desinteresadas" para ayudarlos a salir de las adversidades, y buscaba encauzarlos a través de la vigilancia de sus actos, los "sanos consejos" y la "recta educación". Como su amor era inmenso, podía tolerar los defectos de sus hijos y perdonarlos por sus acciones, sin importar su gravedad o el daño moral que causaran. ${ }^{48}$

El materno era el único amor que podía considerarse "verdadero" en virtud de que involucraba el "amor-sacrificio", el "amor-generosidad", el "amor-desinterés" y el "amor-lealtad". ${ }^{49}$ El sacrificio y la abnegación, entendidos como las principales virtudes de la madre, se trasladaron al discurso cinematográfico, tal como se puede constatar en películas como Mi madrecita y Cuando los hijos se van. La primera buscaba consolidar la celebración del día de la madre y del amor materno en el imaginario nacional. De hecho, se le consideró la "película emblema" de la festividad. La historia era cíclica: comenzaba y culminaba un 10 de mayo. El inicio era doloroso. La protagonista, María (Sara García), recibía la noticia de que sus hijos no la acompañarían en el festejo y uno de ellos, Julio (Julián Soler), le pidió apoyo económico para marchar a Estados Unidos, a fin de lograr su sueño de ser barítono. Para conseguir el dinero, María decidió hipotecar su rancho. Cuando Julio lo recibió, su novia Margot exclamó "bendita sea tu madre Julio, que vive y se sacrifica por ti”. Aunque Julio le mandó dinero a su madre para saldar las deudas, su hermano Luis (Víctor Urruchúa) no se lo entregó y María perdió si propiedad. Ante tal situación, María viajó a la ciudad de México para pedir el apoyo de sus hijos Enriqueta (Julieta Palavicini) y Luis, quienes no sólo se negaron a hacerlo, sino que ocultaron quién era. Sin dinero y con gran pesar por el desprecio de sus vástagos, María visitó la basílica de Guadalupe en donde co-

47 Elisabeth Badinter (1981, p. 223) menciona que estos dos atributos se le otorgaron a la madre en el siglo xIX. La abnegación se refería a su vocación altruista y el sacrificio al orden moral.

${ }^{48}$ T. Coelho, “¡Madre!”, El Siglo, 10 de mayo de 1922, pp. 3-4; “Al margen”, El Siglo, 10 de mayo de 1927, p. 1; D. Garza, "A la madre", El Siglo de Torreón, 10 de mayo de 1935, p. 2; F. Juambelz, "La madre", El Siglo de Torreón, 10 de mayo de 1935, p. 2; "Hoy se celebra el día de la madre”, El Siglo de Torreón, 10 de mayo de 1942, pp. 1, 7; C. Díaz, “¡Madre!”, El Siglo de Torreón, 10 de mayo de 1946, p. 4; "Madre”, El Informador, 10 de mayo de 1949, p. 4.

49 D. Quevedo, “¡Loor a las madres!”, El Siglo de Torreón, 10 de mayo de 1950, pp. 4, 11. 
noció a un hombre que le ofreció trabajo. Al no recibir noticias de su madre, Julio regresó a México y descubrió que el rancho había sido embargado, por lo que pagó parte de la deuda y emprendió la búsqueda de su madre. Al darse cuenta de la ingratitud de sus hermanos, el cantante le expresó a Enriqueta que "hasta en las fieras más viles, entre los lobos y los chacales, está desarrollado el instinto primario, fundamental, del amor a la madre".

Como se acercaba el 10 de mayo, el hombre que contrató a María le informó que le daría libre el día por ser "una fecha que todos los hombres debíamos considerar como sagrada", pero ella le respondió que no tenía hijos. Por azares del destino, Julio descubrió que su madre trabajaba en el mismo edificio en donde estaba la oficina de Luis y cuando se enteró de que este la estafó, lo golpeó y lo llevó a rastras para que le pidiera perdón. María se reconcilió con sus hijos y la película termina con su arribo al rancho para festejar el 10 de mayo. El final resulta significativo, pues Julio comparó los sufrimientos de su madre con los de la virgen María. En el caso de Cuando los hijos se van, la historia se centra en torno a José Rosales (Fernando Soler), su esposa Guadalupe (Sara García), sus hijos José (Carlos López Moctezuma), Raimundo (Emilio Tuero), Amalia, Federico y Tomás, y su amigo Casimiro (Joaquín Pardave). Uno de los momentos fundamentales de la película es cuando Casimiro le regala un radio a Guadalupe por ser 10 de mayo. Al recordarle la fecha, ella mencionó "qué raro, qué raro que todavía haya alguien que se acuerda que soy madre", expresión producto de que ninguno de sus hijos los visitaba y a que de uno de ellos, Raimundo, no sabía nada porque su padre lo corrió de la casa. A causa de la enfermedad de José, Guadalupe pidió dinero prestado y el agiotista se presentó para embargar varios objetos, entre ellos la radio, pero ella solicitó que se le permitiera escuchar a Raimundo que iba a cantar en un concierto y era "una canción que me dedica a mí". El agiotista aceptó a regañadientes. Cuando Raimundo externó que estaba "amargado porque mi madre perdió un día la fe en mí", ella respondió que "nunca la perdí hijo, nunca, ¿por qué lo dices? Yo nunca perderé la fe en mis hijos y menos en ti que en ninguno".

Debido a un "problema económico" de su hijo José, Guadalupe hipotecó la casa pero le firmó un papel en blanco al agiotista, circunstancia que este aprovechó para tratar de quedarse con el inmueble. Ante este problema, $\mathrm{Ca}-$ simiro decidió pedirles ayuda a los hijos de los Rosales, pero sólo Raimundo respondió a la petición. Ante la negativa del agiotista de reconocer el verdadero monto del préstamo, Raimundo decidió encararlo y murió para salvar a sus 
padres del despojo. Aunque el padre mostró su pesadumbre por la ingratitud de sus hijos, Guadalupe tenía fe en que ellos regresarían pues "en todos ha de florecer la verdad por el sacrificio de su Raimundo”. La película termina con los hijos reunidos en torno a la mesa, quienes solicitaban el perdón por sus acciones. Como se puede apreciar, las dos películas enfatizaban tres valores que caracterizaban el ideal de la madre: el sacrificio, la abnegación y el perdón. Aunque los dos filmes tenían un final feliz para la protagonista resulta interesante resaltar que las problemáticas que vivían las madres fueron resueltas por el hijo predilecto, quien a pesar de ser despreciado y humillado por su familia, lograba triunfar y se imponía como un ejemplo moral para los demás. En la primera película, las palabras de Julio determinaron que Enriqueta decidiera abandonar un matrimonio que la hacía infeliz, en tanto que en la segunda el padre reflexionó sobre los errores que cometió con Raimundo.

\section{"EL DEBER DE LOS DEBERES" O EL AMOR DEL HIJO A LA MADRE}

Si para los escritores de la época el amor de la madre era "el más grande de los amores", el de los hijos a la madre debía constituirse en el "deber de todos los deberes", pero ellos no cumplían con su misión a causa de su orgullo y de que no proseguían las buenas enseñanzas de sus madres, lo que hacía que sus almas fueran "cobardes", "degeneradas", "viciosas" y que acallara "la voz del agradecimiento y del cariño filial". Los hijos debían comprender que su progenitora era la única mujer que merecía veneración. Para rendirle un "justo homenaje", no se necesitaba comprar un regalo, sino seguir sus enseñanzas que permitirían tener una "conducta intachable", "un corazón sano" y "una confianza ilimitada" en sus consejos. El principal presente que esperaba recibir una madre era la felicidad de sus vástagos y que destacaran por "virtudes espirituales" como la honradez, la rectitud, la honorabilidad y la personalidad. ${ }^{50}$ Así, el buen hijo era aquel que amaba a su madre, obedecía sus órdenes, seguía sus consejos, la honraba, la respetaba y la cuidaba. Todo

50 "Día de las madres", El Siglo, 10 de mayo de 1922, p. 1; "Al margen”, El Siglo de Torreón, 10 de mayo de 1928, p. 1; E. Borrego, "Diez de Mayo", El Siglo de Torreón, 10 de mayo de 1929, pp. 3, 6; "Día de las madres", El Informador, 10 de mayo de 1933, p. 3; E. Jiménez, "Madre", El Siglo de Torreón, 10 de mayo de 1935, p. 2; F. Juambelz, "La madre", El Siglo de Torreón, 10 de mayo de 1935, p. 2; S. Silva, “'Salve, madres!”, El Siglo de Torreón, 10 de mayo de 1944, p. 4; J. P. González, 
ello se constituía en el único camino para transitar por el "camino florido de la rectitud moral". El "corazón puro" de la madre estaba dispuesto a perdonar las malas acciones de sus hijos, quienes podían encontrar redención, esperanza y misericordia en ella, debido a que su alma albergaba los "afectos más puros" y los "sentimientos más santos", lo que la convertía en "el sustantivo de los sustantivos". El sacrificio de los hijos también se consideraba un bien preciado, tal como se podía observar en un breve relato de un presidiario llamado Pedro que se escapó de la cárcel para despedirse de su madre moribunda, aun a sabiendas de que su castigo podría ser mayor. A los "buenos hijos" se les pedía que no sólo buscaran festejar a sus madres, sino que también lo hicieran con aquellas que sufrían por causa de la pobreza o del alejamiento de sus hijos. A esas madres "incomprendidas y olvidadas" también se le debía dar muestras de cariño. ${ }^{51}$

\section{"EL DÍA DE LOS DÍAS": LOS FESTEJOS DEL DÍA DE LA MADRE EN TORREÓN Y GUADALAJARA}

Los artículos revisados en El Siglo de Torreón y El Informador daban cuenta de que la festividad del día de la madre sufrió diversas transformaciones entre 1922 y 1950. Desde sus inicios, la festividad era promovida por las principales escuelas de cada ciudad. Algunos articulistas agradecían que los profesores asumieran la organización de esos actos, pues hacer que la gratitud a la madre se convirtiera en un deber ayudaría a la consolidación de tres ideales: la formación de "buenos ciudadanos", la vinculación de los padres de familia con los docentes, y se fortalecería el principio de que el hogar y la escuela eran una "unidad inseparable" en la que se gestaba la ciudadanía. Aunque se recordaba a Alducín como el creador de la solemnidad, se reconocía que cada entidad le había dado su propio matiz. En el caso de Torreón, desde 1927 se acordó que el 10 de mayo sería un día feriado para los alumnos. En

\footnotetext{
"El amor y el dolor", El Siglo de Torreón, 10 de mayo de 1944, p. 4; M. Ramos, "10 de mayo", El Siglo de Torreón, 10 de mayo de 1949, p. 4.

${ }^{51}$ J. Dicenta, "Cuatro años de presidio por un beso de su madre", El Siglo, 10 de mayo de 1922, p. 4; A. Rey, “¡Madre!”, El Informador, 10 de mayo de 1931, p. 13; M. Cosío, "La fiesta de las madres", El Siglo de Torreón, 10 de mayo de 1938, pp. 4-5; J. G. Montoya, "Diez de mayo", El Informador, 10 de mayo de 1939, pp. 3, 5; "En el día de la madre”, El Siglo de Torreón, 10 de mayo de 1942, p. 5; S. Silva, "El amor a la madre”, El Siglo de Torreón, 10 de mayo de 1947, p. 4.
} 
las primeras celebraciones, realizadas entre 1922 y 1929, sólo se invitaba a las madres de los estudiantes de las escuelas en las que organizaban festivales, a quienes se les entregaba un pequeño regalo. También se efectuaban eventos deportivos y bailes. Se pedía que los hombres llevaran en la solapa un clavel rojo en caso de que la madre estuviera viva, y blanco en caso de que hubiera fallecido. ${ }^{52}$ A partir de 1930, la Dirección General de Escuelas (DGE) dispuso que los festivales tuvieran una mayor audiencia, por lo que podía asistir el público en general. Para tal efecto, se distribuyeron programas impresos los cuales también se publicaron en El Siglo de Torreón. En correspondencia con la iniciativa lanzada por Excélsior de premiar a la "madre más prolífica", El Siglo otorgó esa distinción a Refugio Ibarra quien tenía 14 hijos. Como ella residía en la población de Matamoros, el acto de premiación fue organizado por el presidente municipal del lugar, quien le hizo entrega de un pergamino que la declaraba "Reina Madre del Estado de Coahuila", al tiempo que recibió varios ramos de flores por parte de algunos niños.

Para darle un mayor auge a la celebración, el gobierno de Coahuila determinó que en las presidencias municipales se reprodujeran las mañanitas y canciones que fueran alusivas al día. ${ }^{53}$ Como las festividades comenzaban a realizarse fuera de las escuelas, tal como ocurrió en Gómez Palacio, cuyo evento se realizó en la plaza de toros y en Torreón que lo llevó a cabo en el teatro Ulloa, la DGE les recordó a las autoridades municipales, en 1931, que el 10 de mayo no tenía un interés festivo sino educativo, por lo que se debían evitar bailes y canciones "populares" que pervertían "los sentimientos", o la música extranjera "que mata nuestra nacionalidad". Esta excitativa ocasionaría que en 1932 se reunieran varios grupos de docentes para entonar las mañanitas por las calles de la ciudad, además de que la Banda Escolar Municipal ofreció

52 "Celebración del día de la madre", El Siglo de Torreón, 10 de mayo de 1927, p. 1; El Siglo de Torreón, 10 de mayo de 1928, pp. 1-3; "Al margen", El Siglo de Torreón, 10 de mayo de 1928, p. 1; "Hoy se festejara con pompa el día de la madre en esta ciudad y en la vecina Lerdo", El Siglo de Torreón, 10 de mayo de 1928, p. 3; "Las fiestas para el día de la madre", El Siglo de Torreón, 10 de mayo de 1928, p. 5; "Al Margen”, El Siglo de Torreón, 10 de mayo de 1930, p. 1; En 1928, las autoridades municipales de Lerdo y Gómez Palacio también autorizaron que el 10 de mayo fuera un día de asueto.

53 "Las fiestas en las escuelas oficiales", El Siglo de Torreón, 10 de mayo de 1930, p. 1; "El día de la madre en C. Lerdo", El Siglo de Torreón, 10 de mayo de 1930, p. 2; “Como se agasajará a la Reina Madre del Estado de Coahuila”, El Siglo de Torreón, 10 de mayo de 1930, p. 6. 
conciertos en los pórticos de algunas escuelas. ${ }^{54}$ Las anteriores actividades se efectuaban en las mañanas y eran independientes a los festivales escolares que se llevaban a cabo en las tardes. Los programas de los festejos eran aprobados por la DGE y se acordó que, a partir de 1934, estuvieran presididos por las sociedades de padres de familia. ${ }^{55}$ También se comenzaron a promover concursos infantiles de composiciones, a fin de cumplir con la petición de la Secretaría de Educación Pública (SEP) respecto de que los niños tuvieran una mayor participación. La celebración del 10 de mayo no se circunscribió al ámbito educativo, pues también se organizaron festivales en la cárcel municipal, la presidencia y las sociedades de padres de familia de los barrios. A partir de 1936, los "gallos" dejaron de ser organizados por los profesores, tarea que fue asumida por grupos formados con ese fin. Ante tal situación, el inspector general de policía determinó que se formara una sola columna. Para facilitar su traslado, la presidencia municipal puso a su disposición varios camiones. ${ }^{56}$ El día de la madre también sirvió como pretexto para causas altruistas, como la que realizó un "grupo de señoritas" que vendía claveles con la inten-

54 "Fiestas escolares para las madres", El Siglo de Torreón, 9 de mayo de 1931, pp. 1-2; "El día de las madres y las fiestas aquî", El Siglo de Torreón, 9 de mayo de 1931, p. 2; "Hubo fiestas en algunas escuelas", El Siglo de Torreón, 10 de mayo de 1931, p. 1; "Juegos en honor de las madres", El Siglo de Torreón, 10 de mayo de 1931, p. 1; "El Día de la Madre hoy en Gómez Palacio”, El Siglo de Torreón, 10 de mayo de 1931, p. 6; "Las fiestas del día de la madre", El Siglo de Torreón, 10 de mayo de 1932, p. 1; "Día de la madre en escuelas de Gómez Palacio", El Siglo de Torreón, 10 de mayo de 1932, p. 3.

${ }^{55}$ Esta disposición buscaba incorporar a los padres de familia en la campaña tendente a eliminar la injerencia del clero en la educación. De hecho, se pensaba que este era el principal enemigo de la escuela pública y el fanatismo religioso se consideraba como la "más grave de las lacras sociales" (Muriá, 1988, p. 508).

56 "Al margen", El Siglo de Torreón, 10 de mayo de 1933, p. 1; "Entusiastamente rendirán hoy homenaje a la madre todos los escolares del Estado Nayarita", El Informador, 10 de mayo de 1933, p. 4; "Fiestas escolares para las madres", El Siglo de Torreón, 10 de mayo de 1934, pp. 1-2; "Los homenajes de hoy a las madres", El Siglo de Torreón, 10 de mayo de 1935, p. 1; "Honor a la madre", El Informador, 10 de mayo de 1935, pp. 1-2; "Las fiestas a la madre aquí", El Siglo de Torreón, 10 de mayo de 1936, pp. 1, 6; "Preparativos para el día de la madre”, El Informador, 10 de mayo de 1937, p. 3; "Homenaje a las madres", El Siglo de Torreón, 10 de mayo de 1938, p. 2; "El día de la Madre será celebrado con entusiasmo en Lerdo y Gómez Palacio", El Siglo de Torreón, 10 de mayo de 1939, p. 2. En Colima y Durango, "el gallo" comenzó a realizarse a partir de 1937. El de Durango se caracterizaba por estar a cargo de los niños. Dos años después, Lerdo y Gómez Palacios se unirían a esta tradición musical. En Lerdo, los principales festejos se efectuaban en el monumento a la madre, lugar en el que se montaban guardias. En Durango, los niños concurrían al panteón para depositar una ofrenda floral en honor a la madre desaparecida, misma situación que ocurría en Nayarit en donde los alumnos montaban guardias de honor mientras algunos huérfanos leían composiciones. 
ción de reunir fondos para los huérfanos. Aunque la SEP pidió a los profesores rurales, en 1935, que organizaran "actos simbólicos" tendentes a la "dignificación" de la madre campesina y proletaria, esta propuesta sería llevada a la práctica en Torreón hasta 1937, cuando se ordenó que las escuelas rurales realizaran "públicos homenajes a la madre campesina". En 1938 se determinó que los festivales del día de la madre, organizados por el Comité Municipal de Acción Cívica y Deportiva, en el teatro "Isauro Martínez", serían presididos por el presidente municipal y "la madre más anciana", aunque también se les otorgaría un lugar de honor a "la más prolífica" y a "la más joven". El que el Ayuntamiento tomara en sus manos la celebración, ocasionó que se produjeran importantes cambios tales como la idea de construir un monumento a la madre, cuya primera piedra se colocó en 1941, que "el gallo" incluyera a los trabajadores sindicalizados como parte del contingente y que en el festival se regalaran diversos electrodomésticos. Todas las actividades eran transmitidas en vivo por la radiodifusora de la ciudad, misma que además les dedicaba la programación del día. En ciertas ocasiones, organismos privados, como los trabajadores del cinematógrafo, ofrecían banquetes en honor a las madres. Tanto el gobierno estatal como diversos organismos publicaron desplegados para felicitar a las "madrecitas". Con motivo de la entrada de México a la guerra, la Secretaría de la Defensa Nacional ordenó que el festejo de 1943 fuera organizado por la Junta Municipal de Reclutamiento. A los conscriptos se les asignó la tarea de entregar diplomas, medallas y flores a las progenitoras. ${ }^{57}$

Dos años después, la celebración tuvo como principal protagonista a la madre de un piloto del Escuadrón 201. Se decía que con esta acción se buscaba mostrar que la patria no olvidaba a las madres de "nuestros aguiluchos que están en el lejano frente occidental". Por tal motivo, se le pidió a Alfonso G. Alaniz, quien fungía como Director Federal de Educación, que le entregara un ramo de flores y le diera un abrazo fraterno en nombre de su hijo. Los honores a la bandera se incluyeron como uno de los actos protocolarios del festejo de 1945, debido a que se le consideraba "la única representante de nuestra madre nacional, la patria”, esto es, se hizo visible la idea de la madre

57 “Los festejos a las madres”, El Siglo de Torreón, 10 de mayo de 1937, p. 1; "La madre más anciana”, El Siglo de Torreón, 10 de mayo de 1938, p. 1; "Los agasajos a las madres”, El Siglo de Torreón, 10 de mayo de 1938, p. 8; "Fiesta oficial en honor de la madre”, El Siglo de Torreón, 10 de mayo de 1941, pp. 1, 5; "Saludo a las madres durangueñas", El Siglo de Torreón, 10 de mayo de 1942, p. 2; "El banquete a las madres", El Siglo de Torreón, 10 de mayo de 1942, p. 2; "Bellas fiestas en honor de la madre”, El Siglo de Torreón, 10 de mayo de 1943, pp. 1, 7. 
patria. ${ }^{58}$ En 1947 se introdujeron algunas variaciones en la festividad. El "gallo" comenzó a las cuatro de la mañana y a las siete se reunían los grupos en la plaza de los constituyentes, a fin de cantar las mañanitas que las estaciones radiodifusoras transmitían en vivo. A las doce del día, sonaban las sirenas del cuerpo de bomberos para guardar un minuto de silencio por las madres fallecidas. En la tarde se depositaba una ofrenda floral en la tumba de una "madre olvidada" y se ofrecía una comida a la madre más longeva y a la más prolífica, mismas que eran acompañadas al estadio Revolución para observar el festejo organizado por el Ayuntamiento. También se instituyó el concurso de premiar a la primera mujer que diera a luz el 10 de mayo, quien recibía un premio en efectivo. Algunas asociaciones privadas también ofrecieron estímulos a las madres ganadoras, que iban desde estufas hasta dinero. Es de destacar que en 1949 el desfile realizado en el estadio incluyó tres carros alegóricos que representaban a la madre, a la "madre escuela" y a la "madre patria". ${ }^{59}$

En el caso de Guadalajara, las noticias publicadas entre 1922 y 1929 sólo hacían referencia de los festivales realizados en las escuelas de la ciudad, en los cuales siempre estuvo presente Carlos Trinidad Sepúlveda, quien, como representante de Excélsior, pronunciaba un discurso alusivo al evento. En la década de 1930, el festejo comenzó a adquirir un matiz distinto. Por ejemplo, el obispo Francisco Orozco secundó la iniciativa por considerar que ayudaba a "cristianizar algunas manifestaciones de la vida social moderna" ${ }^{60}$ Por su parte, la Confederación Obrera de Jalisco y el Comité Local de la Asociación Nacional de Protección a la Infancia organizaron funciones de cine en honor de la madre, el Partido Nacional Revolucionario (PNR) efectuó un evento y se llevó a cabo un concierto patrocinado por una radiodifusora local. En 1934, el festejo de la madre adoptó un carácter distinto. A la par de los festivales

58 “Se agasajará a la madre de un miembro del 201”, El Siglo de Torreón, 10 de mayo de 1945, p. 1, 16; "Las fiestas a la madre en C. Lerdo", El Siglo de Torreón, 10 de mayo de 1945, p. 2.

${ }_{59}$ "Las fiestas en honor a las madres", El Siglo de Torreón, 10 de mayo de 1947, pp. 1, 11; "Un fervoroso homenaje se rendirá a las madres”, El Siglo de Torreón, 10 de mayo de 1948, pp. 1, 16; "Las fiestas en honor de la madre", El Siglo de Torreón, 10 de mayo de 1949, pp. 1, 10; "Homenaje de gratitud a las madres", El Siglo de Torreón, 10 de mayo de 1950, pp. 1, 10.

60 "Hoy se celebrará el 'Día de la Madre”, El Informador, 10 de mayo de 1925, p. 1; "Festivales para celebrar el día de las madres", El Informador, 10 de mayo de 1926, p. 1; "Hoy se celebra el día de las madres", El Informador, 10 de mayo de 1927, pp. 1, 6; "Será celebrado hoy el día de las madres", El Informador, 10 de mayo de 1928, pp. 1, 8; "El día de la madre será celebrado hoy en las escuelas oficiales", El Informador, 10 de mayo de 1929, pp. 1, 6; "Hoy se celebra el 'día de la madre", El Informador, 10 de mayo de 1930, pp. 1, 6. 
organizados por las escuelas, el gobierno del Estado, a través de la Dirección General de Educación y con el apoyo de la sección femenil del PNR, preparó un evento en el teatro Degollado al que se invitó a todas las "clases sociales". Al igual que en Torreón, la Sociedad de Padres de Familia comenzó a tener injerencia en el diseño de los festivales escolares. El ejército también preparó un festival para las "abnegadas soldaderas" en el Cuartel Colorado, cuyo acto central fue la entrega de un ramo de flores a la "madre más anciana". A partir de 1937 se realizó una ceremonia en el panteón en honor de las madres muertas, y en la función del teatro Degollado se pronunció un discurso encomiástico al 10 de mayo. ${ }^{61}$ Los eventos escolares de 1939 estuvieron marcados por la idea de rendir homenaje a la "mujer-madre", a la "madre-escuela" y a la "madre-proletaria". Como se aprecia, Guadalajara tardó cuatro años en responder a la excitativa de la SEP de honrar a la madre proletaria, aunque no se mencionó nada sobre la madre campesina.

Aunque la organización del festival del teatro Degollado siempre estuvo a cargo de una de las dependencias estatales, sea el Departamento Cultural del Estado o la Dirección General de Educación, entre 1942 y 1950 se contó con el apoyo de instituciones como la Sociedad de Educadoras "Rosaura Zapata" y el Centro Militar Insurgente "Pedro Moreno". En la década de 1940, los eventos para festejar a la madre se diversificaron, pues se ofrecieron conciertos, veladas literarias, desayunos y se les llevaban las mañanitas a las madres ancianas. También se publicaron mensajes de felicitación de las autoridades locales, los prelados y el presidente de la república, Miguel Alemán, y su esposa, Beatriz Velasco. Otras instituciones también prepararon eventos como la policía, la Liga de Industriales, el personal del reformatorio, la Gran Logia Occidental Mexicana y el Club de Leones. A partir de 1947, el 10 de mayo fue declarado día de asueto para los estudiantes. Ese mismo año, en el festival del teatro Degollado se dispuso guardar un minuto de silencio por las "madres desaparecidas", así como entregar utensilios para el hogar, ropa y di-

61 "Sincero homenaje de gratitud y respeto se rendirá hoy a las madres", El Informador, 10 de mayo de 1931, p. 1; “¡Honor a las madres!”, El Informador, 10 de mayo de 1932, pp. 1-2; "Hoy se celebrará con entusiasmo el día de la madre”, El Informador, 10 de mayo de 1934, pp. 1-2; “iLoor a las madres!", El Informador, 10 de mayo de 1936, pp. 1-2; "Hoy es el día señalado para rendir pleitesía a las madres", El Informador, 10 de mayo de 1937, pp. 1, 3; "Hermoso festival listo para hoy", El Informador, 10 de mayo de 1937, p. 8; "Con algunos festejos escolares celebrase el día de la madre", El Informador, 10 de mayo de 1939, p. 1; "Festejos para hoy 'Día de la madre”, El Informador, 10 de mayo de 1940, pp. 1, 7. 
nero en efectivo a las "madres humildes y ancianas", ${ }^{62}$ situación que buscaba mostrar que el Estado se convertía en el protector de las mujeres desvalidas. No se mencionaba quien presidió el evento, pero es probable que fuera la esposa del gobernador. Es de recordar que el reparto de regalos fue una práctica instituida por Soledad Orozco, la esposa de Manuel Ávila Camacho, en 1943, y que prosiguió Beatriz Velasco en el sexenio siguiente.

\section{EL ASPECTO COMERCIAL DEL DÍA DE LA MADRE}

Tanto en Torreón como en Guadalajara, los periódicos resaltaban el carácter privado que comenzó a tener el día de la madre, pues se subrayaba que se llevaban a cabo reuniones familiares en las que se les entregaban regalos y flores como un reconocimiento a sus "sacrificios". Si bien algunas voces críticas pedían que la celebración del día de la madre no se convirtiera en un asunto comercial, lo cierto es que en los dos periódicos se enfatizaba que las ventas aumentaban días antes de la celebración. De hecho, en varios artículos de El Siglo de Torreón se manifestaba la emoción de observar que "la mayoría de la clientela estaba compuesta de niños y niñas, de clase humilde, que ajustaban su regalo al poco dinero con el que contaban", a quienes, en ciertas ocasiones, algunas "personas caritativas" les compraban el obsequio que deseaban. Se decía que como el número de compradores excedía el tamaño de los establecimientos comerciales, se les dejaba pasar en grupos y se cerraban las puertas para poder atenderlos. Ante la gran afluencia de compradores, la presidencia municipal de Torreón autorizó que las tiendas de regalos cerraran una hora

${ }_{62}$ "El día de la madre hoy en el Degollado", El Informador, 10 de mayo de 1942, p. 10; "En honor de las madres", El Informador, 10 de mayo de 1942, p. 11; "Homenaje a la madre", El Informador, 10 de mayo de 1942, p. 12; "Festival en honor de la madre", El Informador, 10 de mayo de 1943, pp. 1-2; "Fiesta a la madre", El Informador, 10 de mayo de 1943, p. 11; "Festejos del día de la madre”, El Informador, 10 de mayo de 1945, pp. 1, 3; "Entusiasta celebración, hoy, del 'Día de la Madre", El Informador, 10 de mayo de 1946, pp. 1, 3; "Bendición papal a las madres", El Informador, 10 de mayo de 1946, p. 1; "Los festejos a la madre", El Informador, 10 de mayo de 1947, pp. 1-2; "S. S. el papa envía a las madres mexicanas su bendición apostólica", El Informador, 10 de mayo de 1948, p. 1; "La policía rendirá homenaje a la madre", El Informador, 10 de mayo de 1948, pp. 8, 10; "Lucidísimo resultó ayer el festival en honor de la madre en el Estadio", El Informador, 10 de mayo de 1948, p. 15; "Celebración del día de las madres en esta ciudad", El Informador, 10 de mayo de 1949, p. 1; "Mensaje de felicitación”, El Informador, 10 de mayo de 1949, p. 3; "Sociales", El Informador, 10 de mayo de 1949, p. 7; "Los festejos de la madre", El Informador, 10 de mayo de 1950, pp. 1-3. 
después de lo permitido. Los presentes no sólo se adquirían en la zona comercial, sino también con los vendedores ambulantes que se instalaban en los alrededores. Una situación similar ocurrió en Guadalajara, pues se advertía de los "grupos de jovencitas y muchachos con grandes y pequeños paquetes, $y$ en sus caras expresiones de íntima satisfacción". ${ }^{63}$ Los anuncios publicitarios que invitaban a comprar regalos para las madres comenzaron a aparecer, tanto en uno como en otro periódico, en la década de 1930. En un principio, se ofrecía ropa, alhajas, flores, jabones, perfumes, productos de belleza, pasteles y abarrotes, pero en la década de 1940 predominaban los que ofrecían diversos tipos de electrodomésticos, situación que evidenciaba los cambios que la modernidad introducía en México y cuyo consumo fue alentado por la publicidad (Rocha, 1996, p. 131).

Resulta significativo que en los anuncios de la década de 1940 predominara la imagen de la madre anciana, la cual, según se decía en uno de ellos, representaba el "lazo de unión" en la familia y simbolizaba el "recio tronco familiar", a diferencia de la "madre joven" que principiaba "su noble y santa vida". El papel central que se le otorgaba a la madre anciana también se advertía en diversos espectáculos, pues a ellas se les permitía el ingreso de manera gratuita, lo que constituía, según los organizadores de los eventos, una forma de rendir homenaje a las "cabecitas blancas", mismas que, como ya se mencionó, constituían el estereotipo de la madre por excelencia. ${ }^{64}$

\section{A MANERA DE CONCLUSIÓN}

En los últimos años, se han publicado una serie de estudios que reflexionan y cuestionan el papel otorgado, social y culturalmente, a la maternidad (Badinter, 1981, 2011; Barceló, 2016; Tubert, 1996). Asimismo, se ha advertido

63 "Los festejos a las madres", El Siglo de Torreón, 10 de mayo de 1937, p. 6; "Con entusiasmo se celebrará el día de la madre”, El Siglo de Torreón, 10 de mayo de 1944, pp. 1, 12; "El entusiasmo por agasajar a las madres en su día”, El Siglo de Torreón, 10 de mayo de 1945, pp. 1, 14; "Ayer se notó mucho movimiento en el comercio", El Informador, 10 de mayo de 1945, p. 1; "Festejos del día de la madre", El Informador, 10 de mayo de 1945, pp. 1, 3; "El homenaje a las madres", El Siglo de Torreón, 10 de mayo de 1946, pp. 1, 10; "Entusiasta celebración, hoy, del 'Día de la Madre”, El Informador, 10 de mayo de 1946, pp. 1, 3; "Homenaje de gratitud a las madres”, El Siglo de Torreón, 10 de mayo de 1950, pp. 1, 10.

${ }_{64}$ “Dos cariños!”, El Informador, 10 de mayo de 1944, p. 7; “La Nacional”, El Informador, 10 de mayo de 1946, p. 5. 
sobre la necesidad de analizar el imaginario y las prácticas que lo han constituido (Gutiérrez, 2017; Palomar, 2005). La idealización del amor materno sería cuestionado, en un primero momento, en la década de 1960 cuando los planteamientos feministas buscaron disociar a la mujer de la madre (Palomar, 2005, p. 42). El ideal de la mujer madre, como se advirtió en el estudio, predominó en el discurso de los dos periódicos estudiados, mismos que mostraban los diferentes significados que se le atribuyeron a la maternidad. En un primer ámbito, se enfatizaba el aspecto biológico pues engendrar hijos constituía una característica "innata" de su ser, es decir, se naturalizaba el papel de la mujer como madre, aspecto que, en un segundo momento, se vigorizaba con un discurso que integraba elementos religiosos e ideológicos. Por el hecho de ser madre, la mujer adquiría las mismas cualidades que identificaban a la virgen María, quien constituía la "mujer perfecta" de acuerdo con el pensamiento católico, pero también se le atribuía cierta cercanía con lo divino por su capacidad de crear vida. Las ideas religiosas se complementarían con aquellas gestadas desde el pensamiento eugenésico y pronatalista que buscaban el crecimiento poblacional, motivo por el que se buscó premiar a las madres más prolíficas, pero también la figura de la madre adquirió ciertos matices que fueron producto de las circunstancias políticas, económicas o ideológicas del momento. Ejemplo de lo anterior es que la mujer madre se transfiguró en madre-patria tras el ingreso de México a la segunda guerra mundial, el ensalzamiento de la madre campesina tras el ascenso de Lázaro Cárdenas a la presidencia o el papel que se le asignaba como consejera de los hombres en cuestiones políticas.

Lo anterior muestra que, si bien se buscaba afianzar el deber ser femenino, desde la asociación de su papel como mujer-madre, también se utilizaba su figura para discutir ciertos aspectos como la necesidad de que el campo se modernizara o que se estableciera una nueva legislación que cuidara de los intereses de las mujeres en lo general, aunque no se le buscó reconocer sus derechos políticos. En el discurso periodístico se reconocía que las madres eran objeto de abuso, tanto de sus esposos como de sus hijos, y aunque no se apoyaban las ideas "modernas", sobre todo las que se referían a la decisión sobre la maternidad, sí se pensaba en cambiar la mentalidad de la sociedad con la intención de mejorar las condiciones de las mujeres y, con ello, hacer que el país adquiriera una faceta moderna. En este sentido, se consideró a la escuela y a los niños como los mejores instrumentos para difundir los principios e ideales en los que se debía sustentar el culto a la madre, a lo cual también 
se debe sumar la difusión que los periódicos le dieron a los festivales que en un primer momento se organizaban en las instituciones educativas, pero que con el transcurrir de los años fueron también preparados por diversas dependencias gubernamentales, organizaciones sindicales y grupos empresariales, entre otros, lo cual supuso que la celebración saliera de un ámbito particular, como lo era la educación, para adquirir un carácter colectivo y, de esa manera, lograr que el mensaje que se buscaba difundir tuviera un mayor impacto entre todos los sectores sociales. Aunque existieron algunos asuntos en los que se siguieron las acciones que se llevaban a cabo en la ciudad de México, tal como ocurrió con las premiaciones que enfatizaban ciertas características de las madres, lo cierto es que en cada ciudad se buscó imprimirle un toque especial a la festividad.

Así, los "gallos", las guardias en los panteones o el minuto de silencio en honor de las madres muertas daba cuenta de las formas en las que los diversos grupos sociales se apropiaban de la celebración. La celebración del día de la madre tendía a incentivar el aspecto festivo, pero los discursos y ceremonias evitaban hablar de los problemas que vivían y padecían en su acontecer cotidiano. El énfasis puesto en la madre ocultaba a la mujer que, como un ser social, tenía derechos que no eran reconocidos por una sociedad dominada por los hombres. Para comprender las razones por las cuales la idealización de la maternidad y de la festividad del 10 de mayo adquirieron relevancia en la sociedad mexicana de la primera mitad del siglo $\mathrm{xx}$, se requiere realizar un mayor número de estudios a nivel local, pues, como se muestra en este estudio, el análisis de los discursos periodísticos no sólo permite mostrar las convergencias en cuanto a la construcción de un discurso que idealizaba la maternidad y que inducía a las mujeres a que cumplieran con el papel que la naturaleza les había asignado, papel que también se enfatizaba en rotativos de la ciudad de México como Excélsior, lo cual significaba abandonar sus ideales de contar con un trabajo o que se les reconocieran sus derechos sociales y políticos, sino que también posibilita entender las formas que adquiría una festividad en contextos socioculturales distintos, mismas que podían estar determinadas por el tipo de nexos familiares que se construían a nivel local, por la función que asumían las autoridades escolares y políticas en esos festejos, por el involucramiento que tenían diversos actores sociales y económicos, y por factores ideológicos que enfatizaban ciertos aspectos relativos a la madre mujer. 


\section{LISTA DE REFERENCIAS}

Arvelo, L. (2004). Maternidad, paternidad y género. Otras miradas, 4(2), 92-98. Recuperado de https://www.redalyc.org/articulo.oa?id=18340203

Ávila, Y. (2004). Las mujeres frente al espejo de la maternidad. La Ventana. Revista de Estudios de Género, 20, 55-100. DoI: https://doi.org/10.32870/lv.v2i20.704

Badinter, E. (1981). ¿Existe el amor maternal? Historia del amor maternal. Siglos XVII a xx. Barcelona: Paidós/Pomaire.

Badinter, E. (2011). La mujer y la madre. Un libro polémico sobre la maternidad como nueva forma de esclavitud. Madrid: La Esfera de los Libros.

Barceló, M. I. (2016). Un camino hacia la maternidad pospatriarcal. AIBR. Revista de Antropología Iberoamericana, 11(1), 131-152. DoI: https://doi.org/10.11156/aibr.110107

Belmonte, C. A. (2016). El cine de la comedia ranchera durante el socialismo a la "mexicana". Revista de El Colegio de San Luis, vI(11), 176-205. DoI https://doi. org/10.21696/rcsl6112016433

Burkholder, A. (2009). El periódico que llegó a la vida nacional. Los primeros años del diario Excélsior (1916-1932). Historia Mexicana, 58(4), 1369-1418. Recuperado de https://historiamexicana.colmex.mx/index.php/RHM/article/view/1678

Castilla, M. V. (2005). La ausencia del amamantamiento en la construcción de la buena maternidad. La Ventana. Revista de Estudios de Género, 22, 188-218. DoI: https:// doi.org/10.32870/lv.v3i22.787

Coontz, S. (2006). Historia del matrimonio. Cómo el amor conquistó el matrimonio. Barcelona: Gedisa.

Cruz, R. (2013). Nueva Era y la prensa en el maderismo. De la caída de Porfirio Díaz a la Decena Trágica. México: UNAM.

García, A. (2015). El amor como problema sociológico. Acta Sociológica, 66, 35-60. DoI: http://dx.doi.org/10.1016/j.acso.2015.05.002

González, T. (2008). El aprendizaje de la maternidad: discursos para la educación de las mujeres en España (siglo xx). Convergencia. Revista de Ciencias Sociales, 46, 91117. Recuperado de https://convergencia.uaemex.mx/article/view/1342

Gutiérrez, A. T. (2017). El 10 de mayo 'Día de la Madre' o de cómo imponer un modelo de maternidad. Xihmai, 12(23), 45-60. Recuperado de http://www.lasallep.edu. $\mathrm{mx} /$ revistas/index.php/xihmai/article/view/394

Knight, A. (2010). La revolución mexicana. Del porfiriato al nuevo régimen constitucional. México: Fondo de Cultura Económica.

Melche, J. E. (1997). La mujer en el cine mexicano como figura fílmica y realizadora. Revista de la Universidad de México, 557, 24-27. Recuperado de https://www. 
revistadelauniversidad.mx/articles/77497687-2f52-4396-a4db-4a9760d07e09/

la-mujer-en-el-cine-mexicano-como-figura-filmica-y-realizadora

Monsiváis, C. (2004). La Santa Madrecita Abnegada: la que amó al cine mexicano antes de conocerlo. Debate Feminista, 30, 157-173. Dor: https://doi.org/https://doi. org/10.22201/cieg.2594066xe.2004.30.1053

Muriá, J. M. (1988). Breve historia de Jalisco. México: SEP/Universidad de Guadalajara.

Sánchez, N. (2016). La experiencia de la maternidad en mujeres feministas. Nómadas, 44, 256-267. DoI: https://doi.org/10.30578/nomadas.n44a14

Oiberman, A. (2005). Historia de las madres en occidente: repensar la maternidad. Psicodebate, 5, 115-130. DoI: https://doi.org/10.18682/pd.v5i0.456

Palomar, C. (2005). Maternidad: historia y cultura. La Ventana. Revista de Estudios de Género, 3(22), 35-67. DoI: https://doi.org/10.32870/lv.v3i22.782

Pérez, R. (1999). Un nacionalismo sin nación aparente. (La fabricación de lo "típico" mexicano. 1920-1950). Política y Cultura, 12, 177-193. Recuperado de https://polcul. xoc.uam.mx/index.php/polcul/article/view/231

Rocha, M. E. (1996). Los comportamientos amorosos en el noviazgo, 1870-1968. Historia de un proceso secular. Historias, 35, 119-139. Recuperado de https://mediateca. inah.gob.mx/repositorio/islandora/object/articulo\%3A18295

Robles, O. (2005). Identidades maternacionales en el cine de María Novaro. Nueva York: Peter Lang Publishing.

Santillán, M. (2010). El discurso tradicionalista sobre la maternidad: Excélsior y las madres prolíficas durante el avilacamachismo. Secuencia, 77, 89-110. DoI: https:// doi.org/10.18234/secuencia.v0i77.1117

Santillán, M. (2019). Maternidad y transgresiones penales en el Distrito Federal, 1940-1950. Historia Mexicana, 68(3), 1121-1164. DoI: http://dx.doi.org/10.24201/ hm.v68i3.3812

Tubert, S. (1996). Introducción. En S. Tubert (ed.), Figuras de la madre (pp. 7-32). Madrid: ediciones Cátedra.

Van Dijk, Teun A. (1996). Opiniones e ideología en la prensa. Voces y Culturas, 10, 9-50. Vargas, M. (1999). La Comarca Lagunera. De la revolución a la expropiación de las haciendas, 1910-1940. México: unAm. 


\section{OTRAS FUENTES}

\section{Hemerografía}

El Informador.

El Siglo de Torreón.

La Voz de México.

Filmografía

Elías, F. (director) (1940). Mi madrecita [película]. Rey Soria Films.

Bustillo Oro, J. (director) (1941). Cuando los hijos se van [película]. Grovas Oro Films. 